\title{
Influence of Lifestyles Related to Eating Habits in Ready Meal Consumption: comparative study between São Paulo and Rome
}

\author{
Influência de Estilos de Vida Associados a Hábitos Alimentares no Consumo de \\ Pratos Prontos: estudo comparativo entre São Paulo e Roma
}

\section{Influencia de Estilos de Vida Asociados a Hábitos Alimenticios en el Consumo de Comidas Preparadas: estudio comparativo entre São Paulo y Roma}

\author{
Paulette Siekierski ${ }^{1}$ \\ Mateus Canniatti Ponchio ${ }^{2}$ \\ Vivian Iara Strehlau ${ }^{3}$
}

Received on March 9, 2012 / Approved on September 24, 2013

Responsible Editor: João Maurício Gama Boaventura, Dr.

Evaluation Process: Double Blind Review

\begin{abstract}
The main objective of this paper was to identify consumers' food-related life style toward ready meals in Brazil and Italy. Our specific objectives were (1) to adapt and validate the Bae, Chae and Ryu (2010) scale and (2) to compare and associate the lifestyles to social-demographic characteristics. Consumers are working longer hours, spending more time in traffic and longing to maximize leisure time, which has been increasingly limited. As a result, they demand products and services that facilitate and support their busy lives. A
\end{abstract}

survey was conducted and the research dataset was comprised of a non-probabilistic sample of 155 questionnaires from Italian consumers from Rome and 200 Brazilians from the city of São Paulo. Among the main results, it was shown that the Romans value the tradition and health dimensions more, whereas consumers from São Paulo value convenience and taste. The gender, age, number of people in the household and type of family variables are associated to the attitudes toward ready meal, as well as with its effective consumption. It is believed that these results

1. Master in Management from Escola Superior de Propaganda e Marketing (ESPM) [dessi@inwind.it]

2. Doctor in Management from Escola de Administração de Empresas de São Paulo of Getulio Vargas Foundation (FGV-EAESP). Professor of the International Management Master and Doctorate programs at Escola Superior de Propaganda e Marketing de São Paulo (ESPM) [mponchio@espm.br]

3. Doctor in Management from Escola de Administração de Empresas de São Paulo da Fundação Getúlio Vargas - FGV-EAESP. Professor of the International Management Master and Doctorate programs at Escola Superior de Propaganda e Marketing de São Paulo - ESPM and Insper [vstrehlau@espm.br]

Authors' address: Rua Dr. Álvaro Alvim, 123, Vila Mariana, São Paulo - SP. CEP 04018-010 - Brasil 
may be relevant both for the development of new products and for the placement of products and brands active in these markets, or even to identify new market segments or understand different generations of consumers.

Keywords: Food-related lifestyle. Consumer behavior - Italy - Brazil.

\section{RESUMO}

O principal objetivo deste trabalho é identificar os estilos de vida relacionados ao consumo de pratos prontos no Brasil e na Itália. Como objetivos específicos têm-se (1) validar a escala de Bae, Chae e Ryu (2010) nos contextos brasileiro e italiano e (2) comparar e relacionar os estilos de vida a características sociodemográficos. Sabe-se que mudanças no estilo de vida de indivíduos do mundo ocidental têm aumentado a demanda por conveniência na preparação das refeições. Consumidores trabalham mais horas, gastam mais tempo no trânsito e desejam maximizar o tempo de lazer cada vez mais limitado, exigindo, assim, produtos e serviços que facilitem e apoiem a vida agitada. Para a pesquisa survey foram coletados dados de 155 consumidores italianos de Roma e 200 brasileiros de São Paulo escolhidos de maneira não probabilística por conveniência. Dentre os principais resultados destaca-se que os romanos valorizam mais as dimensôes tradição e saúde, ao passo que os paulistanos preferem conveniência e sabor. As variáveis gênero, idade, número de pessoas no domicílio e tipo de família possuem associação com os estilos de vida, bem como com o consumo efetivo de pratos prontos. Acredita-se que os resultados apresentados possam ser relevantes tanto para o desenvolvimento de novos produtos como para o posicionamento de produtos e marcas atuantes nesses mercados ou, ainda, para identificar novos segmentos de mercado ou compreender diferentes geraçôes de consumidores.

Palavras-chave: Estilo de vida. Hábito alimentar. Comportamento do consumidor Itália-Brasil.

\section{RESUMEN}

El objetivo principal del trabajo es identificar el estilo de vida de los consumidores brasileños e italianos en referencia al consumo de comidas preparadas. Los objetivos específicos son: (1) validar la escala de Bae, Chae e Ryu (2010), y (2) comparar y relacionar los estilos de vida a las características sociodemográficas. Se sabe que los cambios en el estilo de vida de los individuos del mundo occidental incrementan la demanda de la conveniencia de preparar comidas. Los consumidores trabajan más horas por día, gastan más tiempo en el tránsito y desean maximizar el tiempo de ocio, cada vez más limitado. Así, esos consumidores exigen productos y servicios que faciliten y apoyen su agitada vida. Se realizó una encuesta y se recopilaron datos de 155 italianos en Roma y 200 brasileños en São Paulo, utilizando el muestreo no probabilístico por conveniencia. Los resultados apuntan que los romanos valoran las dimensiones tradición y salud, y los paulistanos prefieren la conveniencia y el sabor. Las variables género, edad, cantidad de personas en el hogar y tipos de familia, están asociadas con las actitudes y el consumo de comidas preparadas. Se cree que los resultados pueden llegar a ser útiles no sólo para el desarrollo de productos nuevos sino para el posicionamiento de productos y marcas operantes en esos mercados, también para la identificación de nuevos sectores, así como la comprensión de las diferentes generaciones de consumidores.

Palabras clave: Estilo de vida. Hábitos alimenticios. Comportamiento del consumidor - Italia - Brasil.

\section{INTRODUCTION}

Changes in the lifestyle of people in the Western world have increased the demand for convenience in meal preparation (COSTA et al., 2007). Consumers have been working longer hours, spending more time in the traffic, and longing to maximize their leisure time, which is 
more and more limited; they therefore require products and services that support and make their hectic lives easier (OLSEN, 2010). As a reaction to such demand, the food industry has expanded its ready-meal options (GEEROMS, VERBEKE, KENHOVE, 2008).

The convenience concept may be applied to different consumption dimensions: a feature inherent in a product, in the product purchase process, the preparation process and storage of such product. Convenience food is defined as any food, fully or partially prepared, for which preparation time, cooking skills or energetic inputs were transferred from the housewife kitchen to a processing or distributing party (SCHOLDERER, GRUNERT, 2005).

Buckley et al. (2005) believe there are a number of factors which influence ready-meal demand: aging of population, changes in family structure, women participation in workforce, longer working hours, consumer prosperity, desire to proceed to healthy foods, individualism, decrease in cooking skills, and desire to spend less time and efforts in meal-related activities, such as shopping, preparing and cleaning foods. Other social-economic and demographic factors which influence this increase in consumption include work regime, family size, income level, time pressure realized and paper overload (VERLEGH, CANDEL, 1999).

In this context, the issue characterizing this research is: how do lifestyles related to eating habits influence ready-meal consumption? In order to answer this question, we identified characteristics of Brazilian consumers in the city of São Paulo and Italian consumers in the city of Rome. Although European eating habits have been relatively frequently studied, there are few studies conducted in Latin America. Accordingly, we expect to contribute with consumer behavior literature based on a comparative empirical study. Bae, Chae and Ryu (2010) detected four factors related to lifestyles regarding ready meals: health orientation, flavor, convenience and tradition.

Therefore, this paper mainly aimed to identify the lifestyles related to ready-meal consumption in Brazil and Italy. Our specific objectives are to validate Bae, Chae and Ryu (2010) scale - designed to measure factors related to lifestyles regarding ready meals - in the Brazilian and Italian contexts, and compare and relate lifestyles to social-demographic characteristics in both countries.

\section{REVIEW OF LITERATURE}

In consumer behavior literature, there are several references to the lifestyle expression, which is defined in several ways. A number of studies aim to relate this variable to consumers' psychographic profiles and consuming habits. Chart 1, below, summarizes some of these references. 


\begin{tabular}{|c|c|}
\hline $\begin{array}{l}\text { Wells and Tigert } \\
(1971)\end{array}$ & $\begin{array}{l}\text { Psychographic studies can define lifestyle and product profiles. They are used by marketing professionals to } \\
\text { define the target market, create a new market view, place a product, better communicate product attributes, } \\
\text { develop a global strategy and place political and social issues in the market. }\end{array}$ \\
\hline Rokeach (1973) & $\begin{array}{l}\text { Basic values are defined as categories to guide human needs. These values can be divided in three guidance cri- } \\
\text { teria, each one subdivided into two psychosocial functions: personal (experimentation and realization), central } \\
\text { (existence and suprapersonal) and social (interactional and normative). }\end{array}$ \\
\hline Bourdie & $\begin{array}{l}\text { The researcher reinforces Weber's proposal and proposes that different class social conditions lead to different } \\
\text { lifestyles. Lifestyles stem from the choice of personal interest of each individual, limited by life possibilities and } \\
\text { influenced by the social group in which the individual is. Lifestyles are evidenced and observed by means of } \\
\text { daily activities, attitudes, values and behaviors. }\end{array}$ \\
\hline $\begin{array}{l}\text { Mowen and Minor } \\
(1998)\end{array}$ & $\begin{array}{l}\text { They introduce idea of a group lifestyle, not only an individual one. Therefore, in the very group, values, tastes, } \\
\text { interests and needs are likely to be shared. }\end{array}$ \\
\hline $\begin{array}{l}\text { Sheth, Mital and New- } \\
\text { man (1999) }\end{array}$ & Widely, they argue that lifestyle is how people live. \\
\hline Lambin (2000) & $\begin{array}{l}\text { Presents a psychographic analysis methodology to measure lifestyle profiles which consist in defining a set of } \\
\text { propositions, such as product quality. }\end{array}$ \\
\hline $\begin{array}{l}\text { Wansink and Park } \\
(2000 \mathrm{a} ; 2000 \mathrm{~b})\end{array}$ & $\begin{array}{l}\text { They conducted a study on the variables of personality and lifestyles used to differentiate soup preferences. } \\
\text { People with similar lifestyles had the same soup preference. }\end{array}$ \\
\hline $\begin{array}{l}\text { Blackwell, Miniard and } \\
\text { Engel (2001) }\end{array}$ & $\begin{array}{l}\text { For the authors, lifestyle is how people spend their time and money; place social-demographic variables as part } \\
\text { of the "lifestyle" construct. }\end{array}$ \\
\hline Grunert et al. (2001) & Similar lifestyles lead to similar behaviors in connection with eating habits - FRL (food related lifestyle). \\
\hline Solomon (2010) & $\begin{array}{l}\text { Lifestyle refers to a consumer standard which reflects the choices of a person, how they spend their time and } \\
\text { money. Eating culture reflects values of a social group. }\end{array}$ \\
\hline
\end{tabular}

CHART 1 - Lifestyles and their relation to psychographic profiles and consumption habits

Source: The authors.

Food consumption is not limited only to economic reasons. Although this is an important factor in a world in which inequities are significant, consumers adjust and readjust their purchases according to price fluctuation of products usually purchased. If the manufacturer increases the price of a product, this product can be replaced with a cheaper one. According to Wright, Nancarrow and Kwork (2001), eating is important not only as a source of food, but also for the commercial and cultural development between companies. Since the ancient time, food preferences were closely related to cultural development. As consumers get richer, eating is not limited to physiological needs only, but it intends to meet social and psychological needs which are shaped by the culture of the nations where these consumers live.

Geographic, historical and economic contexts of a culture directly influence people's eating preferences. Countries like Greece were, traditionally, geographically open to several influences, whereas others, like the Great Britain, were more isolated. Some countries, like China, have a wide range of regional diversities. In the case of Europe, a history of conquers and invasions resulted in a wide repertoire of spices and exotic foods. Several European elites also benefited from the new products conquerors brought from their trips to Asia, such as pasta, which was later developed in Italy, or even the tea, in Great Britain (ASKEGAARD, 1993).

Bourdieu (1984) linked food consumption to a cultural phenomenon. Late industrialized countries in the Mediterrean and Middle East tend to keep influences of traditions and rural lives. There are, for example, strong cultural differences between Chinese, Greek, French and English traditions. In countries in which family relationships seem to be more significant, more focused on the family, greater importance is given to food. In China, Confucius teachings give greater importance to obedience, authority and good family relationship; therefore, eating out 
with family and friends is fundamental in building informal relationships. As for Greece, both family and relationships with the community are very strong. The importance of food and drink in the orthodox Greek culture is fundamental.

According to Jain (1993), eating is an act to socialize, and refusing any hospitality act, including sharing food, is an insult in certain cultures, such as Arabic countries.

According to Wright, Nancarrow and Kwork (2001), in Europe, as in the United States, the number of divorces of family segregation is higher, which leads to higher rates of sharing of formal family meal events. This leads to opportunities to all, particularly to younger generations, to make their preferences for their own food prevail, which may different from traditional meal food.

In addition to observing family relationships, social layers also represent important data. Bourdieu (1984), on this matter, stated that how people eat distinguish bourgeoisie from other social classes. Tastes for food are shaped by childhood experiences or family standards. The author assigned the taste of the working class to sweet, filling and fat foods. This trend stems from the necessity, which results from the lack of choice and enjoyment of the feeling to be satisfied. The taste idea is a middle class concept, as it means freedom of choice. The contemporary taste for food would be an example for the post-modern eclecticism condition, fragmentation, recycling and lifestyles.

Other trends can also be observed. Great Britain, for example, is linked to the Caribbean in relation to the high level of sugar consumption. In contemporary western societies, sweetness evokes associations with overindulgence, unhealthiness, decayed teeth and obesity. In addition, body control is peculiar to the middle class. Therefore, women with more weight go from a higher social category to a lower one in the understanding of certain societies (JAIN, 1993).

A Vanhonacker et al. (2010) study with 4,828 people, in six European countries
- Norway, Belgium, France, Spain, Italy and Poland -, intended to link lifestyles to eating habits, considering the social-demographic characteristics, attitudes and the consumption behavior of respondents. The study detected that the TFC - traditional food consumers - are middle-aged to seniors, concerned with their health, food and ethnocentrism, and are related to cooking traditions and to the pleasure of cooking, more common in the South of Europe. The nontraditional food consumers, on the other hand, can be easily found in the countries of North Europe, are usually younger, with higher school levels, singles and/or live in smaller families. The vegetarians are more likely to belong to this segment. They practice sports more often, which is probably related to their lower age and higher concern with body weight. They also believe that the practicality of food supports its costs, as they are convenience-driven and prefer food that is easy to by, preserve, prepare and cook. In a study conducted by Askegaard and Madsen (1998), individuals from the Germanic region were characterized as health-conscious; in turn, what stands out in individuals in the Netherlands and Flanders was a relatively traditional pattern of eating strong attitudes, like what is good and what is not good. Individuals from the Brussels, Wallonia and Luxembourg regions were identified by signs of consuming foods coming from a sophisticated culture, enjoying eating out and attaching great importance to sensory pleasure; similar pattern was also found among the French.

Following the same line of research results, Guerrero et al. (2009) concluded that the rural and less educated population has more interest in TFP - traditional food products. On the other hand, people who live in urban centers and have a more hectic life, for purposes of work or study, are not part of this group of preference. In the literature, housewives are pictured as TFC. The TFC have conservative eating habits, and keep their cooking habits over generations. They are also considered health-conscious people, and characterized by the great importance they give 
to taste and originality of food products. As a consequence, for the TFC group the product cost may not be an important attribute when shopping.

Along this same line of thought, Shimp and Sharma (1987) studied TFC ethnocentrism and consumer preference for local products instead of foreign ones. It was also noted that some countries are more heterogeneous than others, which indicates strong local characteristics. Individuals in the same regions are distinguished from the rest of the countries, such as Bavaria, Vienna or French speaking part of Switzerland. This in itself is a reason for aspects of regional consumption patterns not to be seen as aspects of international consumption patterns (BRUNSO, SCHOLDERER, GRUNERT, 2004).

The differences between the European eating cultures hardly mean that there have been no fundamental changes. Instead, they can be considered as an expression of change processes not limited to following homogenization lines of globalization.

As far as this issue is concern, James (1996) indicates four food speeches in British society:

a) The first one is a global speech of food offer regarding homogeneous and standard consumption foods exemplified by the multinational fast-food chains. These products can be consumed both in their original country and in any other location.

b) The second one represents "expatriate foods", the search for authentic otherness - for example, Provence, Toscana and other foreign cuisines. Here, what is consumed is, symbolic, the foreign lifestyle and images with claims for authenticity and tradition.

c) A third speech reported is nostalgia, which is close to what could be called a search for culinary roots.

d) The fourth and last food speech is discussed by James as creolization: the combination of several foods with a number of cultural patterns (ingredients, preparation methods, seasoning, combination etc.) according to conditions.
As mentioned below, three models were find which relate to food consumption lifestyles. According to Reid et al. (2001), the FRL - Food Related Lifestyle - model is a transcultural instrument, which measures consumer attitudes in relation to shopping for, preparing and consuming foods. The FRL instrument shows how people relate food and values. It has been applied and validated by research with national representativeness in several countries. Studies were conducted in Australia, Singapore, France, Germany and Denmark on consumer behavior relating to food products based on lifestyles and food (REID et al., 2001); in Spain and in Germany (BRUNSO, SCHOLDERER, GRUNERT, 2004); in Croatia (KESIC, RAJH, KESIC, 2008); Taiwan (FANG, LEE, 2009), the Republic of Ireland (RYAN et al., 2002; RYAN et al., 2004); in Britain (BUCKLEY et al., 2005); and Korea (BAE, CHAE, RYU, 2010). The model consists of five areas that link values to attributes of food products:

a) Buying mode - procedural knowledge of the acquisition of products, issues about the way people shop for food, characteristics of the decision-making process, the importance of price and product information;

b) Preparation method - investigates the transformation of products purchased in meals and includes the individual's interest in cooking, family participation in meal preparation and meal planning;

c) Quality aspects - includes attributes of a higher order, which can be applied to food in general, including health, novelty, price/quality, taste, freshness and organic products;

d) Consumption situation - covers the distribution of meals throughout the day and the importance of eating out;

e) Buying reason - is part of an element that provides the connection between the food-related actions and values, adding the importance of safety and tradition, social aspects in the eating context and meal expectations. 
Bae, Chae and Ryu (2010) designed the RTE - Ready To Eat - model: this is a model which uses four ready-meal-related factors: health, taste, tradition and convenience. Differences which explain the use of ready-made dishes were found in all four factors studied, yet the most significant ones were convenience and tradition, which resulted in two categories of ready-meal consumers: tradition-oriented (cluster 1), and convenience-oriented (cluster 2). This model was validated by a study done in South Korea (BAE, CHAE, RYU, 2010).

Finally, the Convenience Consumer and FRL model was developed from studies in Britain and the Republic of Ireland (BUCKLEY et al., 2005; RYAN et al., 2002; RYAN et al. 2004).
They used measured that related lifestyles and convenience in consumption of ready meals, such as time pressure, stress, family structure, women participation in the labor market, consumer prosperity etc. Six consumer profiles were identified. Another study responsible for food purchases in France and Britain summarizes two approaches, assuming that the influence of resource constraints on actual convenience behaviors is doubly mediated, first by the perception of resource constraints and then, by convenience-orientation (SCHOLDERER, GRUNERT, 2005).

Chart 2 below lists three multicultural studies which explore lifestyle themes and eating habits of ready meals.

\begin{tabular}{|c|c|c|c|c|}
\hline Studies & $\begin{array}{l}\text { Scales used to measure } \\
\text { lifestyles and eating } \\
\text { habits of ready meals }\end{array}$ & $\begin{array}{l}\text { Size and bre- } \\
\text { akdown of } \\
\text { samples }\end{array}$ & $\begin{array}{l}\text { Data collection } \\
\text { method }\end{array}$ & $\begin{array}{l}\text { Results reported between lifestyles and eating } \\
\text { habits of ready meals }\end{array}$ \\
\hline Reid et al., 2001 & $\begin{array}{l}\text { FRL - Grunert et al. } \\
(2001) \text {, with } 5 \text { dimen- } \\
\text { sion and } 69 \text { indicators. }\end{array}$ & $\begin{array}{l}\text { Five samples: } \\
\text { Australia ( } 300 \\
\text { houses); France, } \\
\text { Great Britain, } \\
\text { Singapore and } \\
\text { Denmark. }\end{array}$ & $\begin{array}{l}\text { Questionnaire } \\
\text { completed by } \\
\text { means of } \\
\text { surveys. }\end{array}$ & $\begin{array}{l}\text { Attitudinal and behavioral factors lead FRL in } \\
\text { each of the countries in the sample. Generally, } \\
\text { Cronbach alpha ratios reported are satisfactory, } \\
\text { equal to or greater than } 0.6 \text {. }\end{array}$ \\
\hline Buckle et al., 2005 & $\begin{array}{l}\text { FRL - Grunert et al. } \\
\text { (2001), } 5 \text { dimensions } \\
\text { and } 69 \text { indicators; } \\
\text { Buckley et al., 2005; } \\
\text { Ryan et al., 2002. }\end{array}$ & $\begin{array}{l}\text { Two samples: } \\
\text { Great Britain } \\
(1,000 \text { houses }) \\
\text { and Republic of } \\
\text { Ireland ( } 1,024 \\
\text { houses). }\end{array}$ & $\begin{array}{l}\text { Questionnaire } \\
\text { completed by } \\
\text { means of sur- } \\
\text { veys. }\end{array}$ & $\begin{array}{l}\text { Results indicate that, generally, the FRL has } \\
\text { reached a high level of measurement equivalence } \\
\text { when applied to samples of Irish and British } \\
\text { consumers. Measurement items in this domain } \\
\text { had the same dimensionality and measured } \\
\text { factors with the same reliability. In addition, the } \\
\text { underlying factors had the same interrelations } \\
\text { and had the same variance in both populations. }\end{array}$ \\
\hline $\begin{array}{l}\text { Bae, Chae and } \\
\text { Ryu, } 2010\end{array}$ & $\begin{array}{l}\text { Adapted from FRL- } \\
\text { Grunert } \text { et al. }(2001) \text {, } \\
5 \text { dimensions and } 69 \\
\text { indicators; Proposal } \\
\text { of a new scale with } 4 \\
\text { dimensions and } 14 \\
\text { indicators. }\end{array}$ & $\begin{array}{l}\text { Pilot validation } \\
\text { test with } 30 \\
\text { consumers and } \\
\text { final test with } \\
480 \text { consumers. }\end{array}$ & $\begin{array}{l}\text { Questionnaires } \\
\text { distributed in } \\
\text { food points of } \\
\text { sale and collec- } \\
\text { ted by the rese- } \\
\text { archer or sent by } \\
\text { email. }\end{array}$ & $\begin{array}{l}\text { The research instrument was designed based on } \\
\text { preceding studies. The questionnaire also consi- } \\
\text { dered cultural differences, as it was designed for } \\
\text { Koreans. It comprises two sections which investi- } \\
\text { gate FRL and social-demographic characteristics } \\
\text { of consumers. }\end{array}$ \\
\hline
\end{tabular}

CHART 2 - Studies relating lifestyles with ready-meal eating habits

Source: The authors. 


\section{METHODOLOGY}

We conducted a survey of nonprobabilistic sample of 355 consumers, 155 respondents of which from the Italian city of Rome and 200 Brazilian respondents from the city of São Paulo. Data was collected through a questionnaire available on the internet in Italian and Portuguese languages from July to October 2011, after rounds of pre-testing from February to June of the same year.

The questionnaire included the identification of the following social-demographic characteristics of the respondent: gender, age, marital status, number of household people, level of education, type of family (single with or without children, married with or without children), working and/or studying, if responsible for food shopping, number of monthly meals made with ready meals, type of ready meal consumed (frozen, fresh, canned or freeze-dried) and net monthly income of the household, and a scale to measure lifestyles before the ready meal adapted from Bae, Chae and Ryu (2010).

\section{I Adjustment and validation of Bae, Chae and Ryu (2010) scale}

Bae, Chae and Ryu (2010) scale adaptation to Italian and Portuguese included the use of translation validation procedures (content and face), as recommended by Costa (2011). Back translations were made, content was checked with literature on the matter and interview with consumers were conducted through face-to-face pre-testing. According to Pedhazur and Schmelkin (1991), scale items need to be submitted to a semantic analysis by specialists and target group consumers. Pre-testing is recommended: according to Beaton et al. (2002), first, target group people answer the questionnaire and are then interviewed to check if they understood what questions meant and answered them accordingly. If respondents raise too many doubts, it is possible to go back to the specialist committee for possible adjustments in questions.

According to Wong, Rindfleisch and Burroughs (2003), in investigation scales with several items, the Likert scale is recommended for data collection on attitudes, beliefs and values, among other latent constructs. Cultural adaptation of a measure, in order to be used in a country other than that in which it was created, requires specific methodology. Translating the text is not enough; cultural adaptation may be required to keep content validity in the target language and target population.

The questionnaire intended to Italian respondents was translated from Portuguese to Italian by a bilingual translator and by the authors in Brazil. In March, one of the authors traveled to Rome, where she spent some days interviewing 20 individuals of the target population to check their understanding of the questions. About thirty interviews were also conducted in the city of São Paulo. Based on interactions with pre-testing participants and discussions with specialists, changes were made in the data collection instrument. The text of items of the scale in Portuguese and in Italian is available from the authors.

Bae, Chae and Ryu (2010) scale contains four dimensions to measure lifestyle before ready meals: health orientation, taste, convenience and tradition. This scale has 14 reflexive items measured in Likert five-point scale. The scale dimensional structure was assessed by the exploratory factor analysis technique, with very satisfactory results. Tables 1 and 2 summarize the results. 
TABLE 1 - Exploratory Factor Analysis - Rome sample

\begin{tabular}{|c|c|c|c|c|c|}
\hline \multicolumn{6}{|c|}{$\begin{array}{l}\text { Extraction of factors by key components. VARIMAX rotation. } \\
\mathrm{N}=148 ; 7 \text { observations with missing values }\end{array}$} \\
\hline Variable & Factor 1 & Factor 2 & Factor 3 & Factor 4 & Commonality \\
\hline Convenience_indicator_02 & 0.874 & -0.056 & 0.266 & 0.034 & 0.839 \\
\hline Convenience_indicator_03 & 0.846 & -0.050 & 0.322 & 0.010 & 0.822 \\
\hline Convenience_indicator_01 & 0.814 & 0.052 & 0.227 & 0.151 & 0.740 \\
\hline Health_indicator_02 & -0.135 & -0.875 & 0.020 & -0.079 & 0.790 \\
\hline Health_indicator_01 & 0.096 & -0.864 & -0.018 & 0.077 & 0.762 \\
\hline Health_indicator_03 & 0.258 & -0.726 & -0.046 & -0.228 & 0.648 \\
\hline Health_indicator_04 & -0.418 & -0.623 & 0.010 & -0.313 & 0.662 \\
\hline Tradition_indicator_03 & 0.173 & 0.094 & 0.905 & 0.026 & 0.858 \\
\hline Tradition_indicator_02 & 0.273 & 0.001 & 0.904 & -0.044 & 0.893 \\
\hline Tradition_indicator_01 & 0.516 & -0.102 & 0.734 & 0.070 & 0.820 \\
\hline Taste_indicator_03 & 0.131 & 0.019 & 0.019 & -0.816 & 0.683 \\
\hline Taste_indicator_02 & -0.306 & -0.172 & 0.058 & -0.783 & 0.739 \\
\hline Taste_indicator_01 & -0.437 & -0.034 & 0.050 & -0.656 & 0.624 \\
\hline Taste_indicator_04 & 0.124 & -0.361 & -0.312 & -0.645 & 0.659 \\
\hline Variance & 3.0998 & 2.6170 & 2.5058 & 2.3183 & 10.5408 \\
\hline$\% \operatorname{Var}$ & 0.221 & 0.187 & 0.179 & 0.166 & 0.753 \\
\hline
\end{tabular}

Source: Prepared by the authors, with the support of Minitab 16 statistical package.

TABLE 2 - Exploratory Factor Analysis - São Paulo sample

\begin{tabular}{|c|c|c|c|c|c|}
\hline \multicolumn{6}{|c|}{$\begin{array}{l}\text { Extraction of factors by key components. VARIMAX rotation. } \\
\mathrm{N}=185 ; 15 \text { observations with missing values }\end{array}$} \\
\hline Variable & Factor 1 & Factor 2 & Factor 3 & Factor 4 & Commonality \\
\hline Convenience_indicator_01 & 0.893 & -0.032 & -0.083 & -0.233 & 0.859 \\
\hline Convenience_indicator_03 & 0.889 & -0.078 & -0.090 & -0.178 & 0.836 \\
\hline Convenience_indicator_02 & 0.850 & -0.094 & -0.178 & -0.246 & 0.823 \\
\hline Health_indicator_02 & 0.002 & -0.902 & 0.040 & 0.042 & 0.817 \\
\hline Health_indicator_01 & 0.163 & -0.816 & -0.067 & 0.027 & 0.697 \\
\hline Health_indicator_03 & 0.176 & -0.764 & 0.069 & -0.038 & 0.621 \\
\hline Health_indicator_04 & -0.188 & -0.759 & 0.264 & 0.097 & 0.691 \\
\hline Taste_indicator_02 & -0.091 & -0.096 & 0.863 & -0.033 & 0.764 \\
\hline Taste_indicator_03 & 0.098 & -0.063 & 0.785 & -0.055 & 0.633 \\
\hline Taste_indicator_04 & -0.134 & -0.143 & 0.759 & -0.010 & 0.614 \\
\hline Taste_indicator_01 & -0.227 & 0.066 & 0.733 & 0.063 & 0.597 \\
\hline Tradition_indicator_03 & 0.068 & 0.037 & -0.012 & 0.893 & 0.804 \\
\hline Tradition_indicator_02 & 0.274 & 0.088 & 0.085 & 0.877 & 0.859 \\
\hline Tradition_indicator_01 & 0.379 & -0.011 & -0.020 & 0.837 & 0.845 \\
\hline Variance & 2.7121 & 2.7018 & 2.6097 & 2.4357 & 10.4593 \\
\hline$\%$ Var & 0.194 & 0.193 & 0.186 & 0.174 & 0.747 \\
\hline
\end{tabular}

Source: Prepared by the authors, with the support of Minitab 16 statistical package.

The solution with four factors related to the Italian sample results (Table 1) explains $75.3 \%$ of the original dada variability. Correlations observed among the 14 indicators are strong evidence to support the expected four-dimension structure. Thus, one can name factor 1 as the “convenience," factor 2 "health opposite," factor 3 "tradition opposite," and factor 4 "taste opposite." The factor scores from this factor analysis model were used as indicators of convenience, health, tradition and taste, respectively, for sample individuals in Rome. The only adjustments made 
were related to factor 2, 3 and 4 scores, which had their signs inverted.

On the other hand, the solution with four factors related to the Brazilian sample results (Table 2) explains $74.7 \%$ of the original dada variability. As expected, indicators which should measure the same dimensions produced high correlations with the same factors. Thus, one can name factor 1 as the "convenience," factor 2 "health opposite," factor 3 "taste," and factor 4 "tradition." The factor scores from this factor analysis model were used as indicators of convenience, health, taste and tradition, respectively, for sample individuals in São Paulo. The only adjustments made were related to factor 2 scores, which had their signs inverted.

\section{DATA ANALYSIS}

To check, initially, the relationship between certain social-demographic variables and each scale dimensions, a set of $t$ tests and chi-square tests of independence are summarized in Tables 3, 4 and 5. The explanation for the choice of these issues to be crosschecked against listed factors is that, as already mentioned, the market growth of ready meals was mainly by the need for convenience, increase of women in the labor market, the emergence of smaller families, increase of single people, consumer prosperity and population aging (REID et al., 2001; RYAN et al., 2002; RYAN et al., 2004; SCHOLDERER, GRUNERT, 2005; BUCKLEY et al., 2005).

TABLE 3 - Chi-square tests of independence between gender and each attitude scale dimension before the ready meal

\begin{tabular}{lccc}
\hline São Paulo & Fem. $^{2}$ & Male $^{2}$ & Total $^{2}$ \\
\hline $1^{\text {st }} \mathrm{Q}-$ health $^{1}$ & 28 & 22 & 50 \\
$4^{\text {th }} \mathrm{Q}-$ health $^{1}$ & 43 & 7 & 50 \\
Total $^{\text {st }}$ & 71 & 29 & 100 \\
$1^{\text {st }} \mathrm{Q}-$ taste $^{1}$ & 36 & 14 & 50 \\
$4^{\text {th }} \mathrm{Q}$ - taste $^{1}$ & 35 & 15 & 50 \\
Total $^{\text {st }}$ & 71 & 29 & 100 \\
$1^{\text {st }} \mathrm{Q}-$ conv. $^{1}$ & 37 & 13 & 50 \\
$4^{\text {th }} \mathrm{Q}-$ conv. $^{1}$ & 37 & 13 & 50 \\
Total $^{\text {total }}$ & 74 & 26 & 100 \\
$1^{\text {st }} \mathrm{Q}-$ trad. $^{1}$ & 31 & 19 & 50 \\
$4^{\text {th }} \mathrm{Q}-$ trad. $^{1}$ & 37 & 13 & 50 \\
Total & 68 & 32 & 100 \\
\hline
\end{tabular}

\begin{tabular}{lccc}
\hline Rome & Fem. $^{\mathbf{2}}$ & Male $^{\mathbf{2}}$ & Total $^{\mathbf{2}}$ \\
\hline 1st $\mathrm{Q}$ - health & 26 & 12 & 38 \\
$4^{\text {th }} \mathrm{Q}$ - health & 35 & 3 & 38 \\
Total & 61 & 15 & 76 \\
$1^{\text {st }} \mathrm{Q}$ - taste & 23 & 15 & 38 \\
$4^{\text {th }} \mathrm{Q}$ - taste & 34 & 4 & 38 \\
Total & 57 & 19 & 76 \\
$1^{\text {st }} \mathrm{Q}$ - conv. & 30 & 8 & 38 \\
$4^{\text {th }} \mathrm{Q}$ - conv. & 26 & 12 & 38 \\
Total & 56 & 20 & 76 \\
$1^{\text {st }} \mathrm{Q}-$ trad. & 32 & 6 & 38 \\
$4^{\text {th }} \mathrm{Q}$ - trad. & 29 & 9 & 38 \\
Total & 61 & 15 & 76 \\
\hline
\end{tabular}

${ }^{1}$ Only respondents classified in the $1^{\text {st }}$ and $4^{\text {th }}$ quarters in the respective factor score distribution were considered in the analyses. ${ }^{2}$ The amounts in the body of the table represent the number or respondents.

Source: The authors.

Chi-square independence tests show that there is evidence that gender and health-orientation are associated in São Paulo (p-value equal to 0.00 ) and in Rome (p-value equal to 0.01); that gender and taste-orientation are associated in
Rome (p-value equal to 0.00), and that gender is not associated with the convenience or tradition orientations. Women are more health-oriented than men in both cities; in Rome, they are also more taste-oriented. 
TABLE $4-T$ tests between age and each attitude scale dimension before the ready meal

\begin{tabular}{lcc}
\hline Age (average) & S. Paulo & Rome \\
\hline $1^{\text {st }} \mathrm{Q}-$ health $^{1}$ & 36.7 & 36.9 \\
$4^{\text {th }} \mathrm{Q}-$ health $^{1}$ & 43.8 & 43.9 \\
T test (sig.) & 0.00 & 0.02 \\
$1^{\text {st }} \mathrm{Q}-$ taste $^{1}$ & 39.8 & 35.5 \\
$4^{\text {th }} \mathrm{Q}-$ taste $^{1}$ & 42.8 & 46.3 \\
T test (sig.) & 0.25 & 0.00 \\
\hline
\end{tabular}

\begin{tabular}{lcc}
\hline Age (average) & S. Paulo & Rome \\
\hline $1^{\text {st }} \mathrm{Q}$ - conv. ${ }^{1}$ & 42.8 & 36.2 \\
4 $^{\text {th }} \mathrm{Q}$ - conv. $^{1}$ & 40.4 & 39.8 \\
T test (sig.) & 0.37 & 0.25 \\
$1^{\text {st }} \mathrm{Q}$ - trad. $^{1}$ & 43.2 & 38.7 \\
4 $^{\text {th }} \mathrm{Q}$ - trad. $^{1}$ & 45.4 & 45.2 \\
T test (sig.) & 0.40 & 0.03 \\
\hline
\end{tabular}

${ }^{1}$ Only respondents classified in the $1^{\text {st }}$ and $4^{\text {th }}$ quarters in the respective factor score distribution were considered in the analyses.

Source: The authors.

The $\mathrm{t}$ tests, which compare the average age of groups of respondents, show that, in Rome, older ones are more health, taste and tradition-oriented, whereas in São Paulo, older ones are more health-oriented, when ready meals are assessed.

TABLE $5-\mathrm{T}$ tests between income and each attitude scale dimension before the ready meal

\begin{tabular}{lcc}
\hline Income (average) & S. Paulo - R\$ & Rome $-€$ \\
\hline $1^{\text {st }} \mathrm{Q}-$ health $^{1}$ & 8,870 & 3,110 \\
$4^{\text {th }} \mathrm{Q}$ - health $^{1}$ & 13,050 & 4,579 \\
$\mathrm{~T}$ test (sig.) & 0.00 & 0.00 \\
$1^{\text {st }} \mathrm{Q}-$ taste $^{1}$ & 9,490 & 2,813 \\
$4^{\text {th }} \mathrm{Q}-$ taste $^{1}$ & 13,650 & 5,196 \\
T test $($ sig.) & 0.00 & 000 \\
\hline
\end{tabular}

\begin{tabular}{lcc}
\hline Income (average) & S. Paulo - R $\$$ & Rome - $€$ \\
\hline $1^{\text {st }} \mathrm{Q}$ - conv. ${ }^{1}$ & 9,190 & 3,671 \\
4 $^{\text {th }} \mathrm{Q}-$ conv. $^{1}$ & 12,750 & 4,237 \\
T test (sig.) & 0.00 & 0.28 \\
$1^{\text {st }} \mathrm{Q}$ - trad. $^{1}$ & 10,210 & 4,316 \\
$4^{\text {th }} \mathrm{Q}$ - trad. $^{1}$ & 10,250 & 4,151 \\
T test (sig.) & 0.96 & 0.78 \\
\hline
\end{tabular}

${ }^{1}$ Only respondents classified in the $1^{\text {st }}$ and $4^{\text {th }}$ quarters in the respective factor score distribution were considered in the analyses.

Source: The authors.

T-tests in Table 5, which compare income per group of respondents, show that, in Rome, people with higher income are more health and taste oriented, and in São Paulo, people with higher income are more oriented health, taste and convenience oriented when assessing their attitudes towards the consumption of ready meals.

In order to compare consumers in both cities according to the attitude scale dimensions toward ready meals, a new exploratory factor analysis was conducted, this time considering all 355 respondents (grouped). This choice is explained by the chance to obtain new factor scores, which, by its comparative nature, can be used to contrast the profiles of respondents in Rome and in São Paulo (it would have made no sense to use the factor scores of segregated analyzes, as they consist of standardized variables with average 0 and variance 1 ). Table 6 summarizes the results. 
TABLE 6 - Average factor scores by attitude scale dimension before ready meal, by city

\begin{tabular}{lcccc}
\hline City & Health & Taste & Convenience & Tradition \\
\hline Rome & 0.12 & -0.21 & -0.06 & 0.07 \\
Sáo Paulo & -0.10 & 0.17 & 0.05 & -0.06 \\
\hline
\end{tabular}

Source: The authors.

Compared to individuals from São Paulo, the Romans value the most tradition and health, whereas São Paulo individuals value more taste and convenience, at least with regard to the consumption of ready meals.

In addition, multiple linear regression models were developed to explain the factor score for each dimension of the scale (health, taste and tradition orientation). As predictor variables, we used the following ones (Chart 3 shows the coding of the variables treated as dummies): a) City - if the respondent is from the city of Rome or São Paulo

b) Age - in years old ('age')

c) Number of households ('number people')

d) Type of family - if single with or without children, or married with or without children

e) Number of monthly ready meals

\section{consumed}

\begin{tabular}{|c|c|c|c|c|}
\hline Type of family & T1 & $\mathbf{T} 2$ & T3 & \\
\hline Single with no children & 0 & 0 & 0 & \\
\hline Single with children & 1 & 0 & 0 & \\
\hline Married with no children & 0 & 1 & 0 & \\
\hline Married with children & 0 & 0 & 1 & \\
\hline City & $\mathbf{C}$ & & & \\
\hline São Paulo & 0 & & & \\
\hline Roma & 1 & & & \\
\hline Number of meals & N1 & $\mathbf{N} 2$ & N3 & $\mathbf{N 4}$ \\
\hline None & 0 & 0 & 0 & 0 \\
\hline$\geqslant 1<5$ & 1 & 0 & 0 & 0 \\
\hline$\geqslant 5<10$ & 0 & 1 & 0 & 0 \\
\hline$\geqslant 10<15$ & 0 & 0 & 1 & 0 \\
\hline$\geqslant 15$ & 0 & 0 & 0 & 1 \\
\hline
\end{tabular}

CHART 3 - Coding of dummy variables included in the regression models

Source: The authors.

\section{I Multiple linear regression model to account for health orientation}

According to the model (Table 7), one can state that:

a) as individuals grow older, the prioritize health orientation; b) Rome individuals, in relation to their São Paulo counterparts, considering that other model variables are fixed, value health orientation less;

c) the higher the number of ready meals consumed (N3; N4), keeping city and age fixed, the less individuals value health dimension. 
TABLE 7 - Multiple linear regression analysis to account for health orientation

\begin{tabular}{|c|c|c|c|c|c|}
\hline \multicolumn{6}{|c|}{ The regression equation is } \\
\hline Predictor & Coef & SE Coef & $\mathrm{T}$ & P & VIF \\
\hline Constant & $-0,873$ & 0.193 & -4.52 & 0.000 & \\
\hline Age & 0.021 & 0.004 & 5.08 & 0.000 & 1.020 \\
\hline N3 & -0.351 & 0.155 & -2.26 & 0.025 & 1.028 \\
\hline N4 & -0.617 & 0.206 & -3.00 & 0.003 & 1.031 \\
\hline City & 0.206 & 0.105 & 1.97 & 0.050 & 1.022 \\
\hline
\end{tabular}

$\mathrm{S}=0.939356 \mathrm{R}-\mathrm{Sq}=12.8 \% \mathrm{R}-\mathrm{Sq}(\mathrm{adj})=11.8 \%$

Only significant variables at the level of $5 \%$ were kept in the model.

Source: The authors, with the support of Minitab 16 statistical package.

\subsection{Multiple linear regression model to account for taste orientation}

According to the model (Table 8), one can state that:

a) age positively influences taste orientation; b) São Paulo respondents, keeping all other independent variables constant, value taste more than their counterparts in Rome;

c) singles with children, in comparison with singles without children, give less importance to taste (keeping "age" and "city" fixed).

TABLE 8 - Multiple linear regression analysis to account for taste orientation

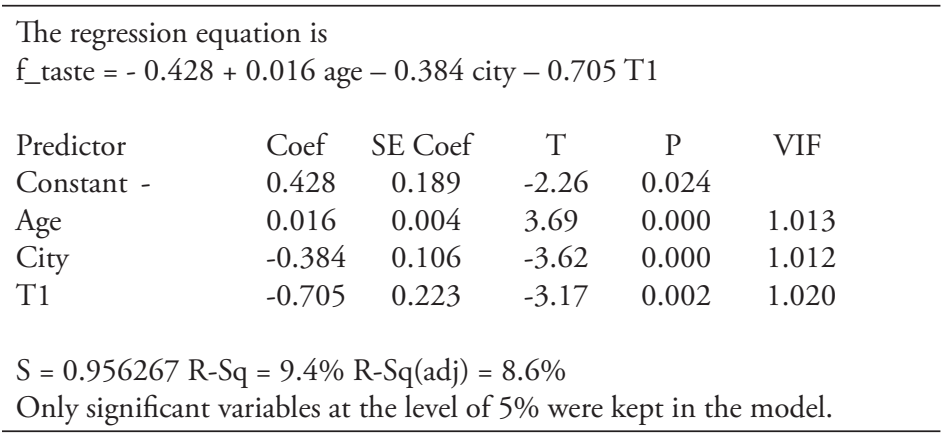

Source: The authors, with the support of Minitab 16 statistical package.

\subsection{Multiple linear regression model to account for convenience orientation}

According to the model (Table 9), one can state that:

a) married individuals, with or without children, in comparison with singles without children (keeping the age variable constant) are more convenience oriented; b) as people grow older, they become less convenience oriented (this result, however, although statistically significant, does not seem to be significant in practice, both for the low "age" ratio value and for the results of analyses presented in Table 4). 
TABLE 9 - Multiple linear regression analysis to account for convenience orientation

\begin{tabular}{llllll}
\hline $\begin{array}{l}\text { The regression equation is } \\
\text { f_convenience }=0.021+0.478 \mathrm{~T} 2+0.710 \mathrm{~T} 3-0.012 \text { age } \\
\text { Predictor }\end{array}$ Coef & SE Coef & $\mathrm{T}$ & $\mathrm{P}$ & $\mathrm{VIF}$ \\
Constant & 0.021 & 0.187 & 0.11 & 0.909 & \\
T2 & 0.478 & 0.198 & 2.42 & 0.016 & 1.178 \\
T3 & 0.710 & 0.137 & 5.19 & 0.000 & 1.628 \\
Age & -0.012 & 0.005 & -2.30 & 0.022 & 1.417
\end{tabular}

$\mathrm{S}=0.965030 \mathrm{R}-\mathrm{Sq}=7.7 \% \mathrm{R}-\mathrm{Sq}(\mathrm{adj})=6.9 \%$

Only significant variables at the level of $5 \%$ were kept in the model.

Source: The authors, with the support of Minitab 16 statistical package.

\subsection{Multiple linear regression model to account for tradition orientation}

According to the model (Table 10), it can be stated that, as you increase the number of ready meals made per month by the respondent, the estimated tradition orientation decreases; this result is in line with the review the literature presented.

TABLE 10 - Multiple linear regression analysis to account for tradition orientation

\begin{tabular}{|c|c|c|c|c|c|}
\hline \multicolumn{6}{|c|}{$\begin{array}{l}\text { The regression equation is } \\
\mathrm{f} \text { _tradition }=0.996-0.431 \mathrm{~N} 1-1.801 \mathrm{~N} 4-1.684 \mathrm{~N} 3-1.489 \mathrm{~N} 2\end{array}$} \\
\hline Predicto & Coef & SE Coef & $\mathrm{T}$ & $\mathrm{P}$ & VIF \\
\hline Cons & 0.996 & 0.193 & 5.16 & 0.000 & \\
\hline N1 & -0.431 & 0.204 & -2.11 & 0.035 & 5.384 \\
\hline N4 & -1.801 & 0.255 & -7.07 & 0.000 & 2.190 \\
\hline N3 & -1.684 & 0.228 & -7.3 & 0.000 & 3.074 \\
\hline N2 & -1.489 & 0.208 & -7.15 & 0.000 & 4.895 \\
\hline
\end{tabular}

$\mathrm{S}=0.796192 \mathrm{R}-\mathrm{Sq}=37.4 \% \mathrm{R}-\mathrm{Sq}(\mathrm{adj})=36.6 \%$

Only significant variables at the level of $5 \%$ were kept in the model.

Source: The authors, with the support of Minitab 16 statistical package.

\section{CONCLUSION}

This paper proposed to deepen the existing knowledge of the influence of lifestyles related to ready meal eating habits by means of a comparative study between Brazilian consumers in the city of São Paulo and Italian consumers in the city of Rome.

One of the objectives referred to the adaptation and validation of the scale of lifestyles related to ready meals of Bae, Chae, Ryu (2010) in the cities of Rome and São Paulo. The results can be considered satisfactory - there is evidence that the dimensional structure of the scale is kept both in São Paulo and in Rome, and the 14 indicators are appropriate to reflect the four dimensions theorized (health, taste, convenience and tradition).

It was possible to detect that the greatest consumers of ready meals are females, people who work and/or study full time, and people who have income that is at a medium-high range.

According to the empirical results, consumers in both cities have different lifestyles as far as ready meals are concerned. In this paper, consumers in Rome are more concerned with tradition and health. For Askegaard and Madsen (1998), in Italy, greater importance is given to the 
sensorial element. Such result is supported by a Vanhonacker et al. (2010) study, which indicates that older population in the South of Europe are more traditional as far as eating is concerned.

No research results were found to indicate the attitudes Brazilian consumers before ready meals. This study indicated that, in São Paulo, more emphasis is given to convenience and taste, in comparison to Rome. The "taste" dimension is supported by anthropologist Da Matta (2001), in the observation that one of the most important Brazilian social mirrors is the food, with what he calls "food code", which theoretically expresses society. According to this author, for the Brazilian individuals, "knowing how to eat is much more refined than the simple act of eating" (DA MATTA, 2001, p. 55). The city of São Paulo is proud to be a gastronomic hub and many of the social activities of its inhabitants are given in gatherings involving food. Simultaneously, the convenience dimension is supported by another characteristic of the city: that it is a huge urban center. Maluf (2000) indicates that contemporary life circumstances and advertisement impacts have changed the way food is acquired or consumed, pointing out the importance of food prepared in the city of São Paulo. Casotti (2001), in research conducted in Rio de Janeiro, suggests that the consumption of frozen and semi-ready meals is related to the convenience in use. As far as the cities are concerned, the following similarity was found, generally: in both cities, healthorientation and gender are related - women are more concerned about their health and generally more taste oriented. Chart 4 below indicates key differences found between the cities:

\begin{tabular}{|l|l|}
\hline Sáo Paulo & Rome \\
\hline Older people are more health oriented. & Older people are more health, taste and tradition oriented. \\
\hline $\begin{array}{l}\text { People with higher income are more health, taste and convenience } \\
\text { oriented. }\end{array}$ & People with higher income are more health and taste oriented. \\
\hline Sáo Paulo individuals value taste and convenience more. & Rome people value tradition and health more. \\
\hline
\end{tabular}

CHART 4 - City related differences

Source: The authors.

Considering the FRL, the following findings can be pointed out: health orientation is more present in older people, Rome individuals tend to value more this dimension than São Paulo individuals and, finally, the higher the number of ready meals made, the less value an individual gives to the health dimension.

Convenience orientation is more present in married individuals than in singles and, as people grow older, they become less convenience oriented. Taste orientation is positively related to age, and Sáo Paulo individual value this style more than Rome individuals. Finally, tradition orientation is more present in those who have few ready meals, in line with the literature.

One of the management implications of this research is better understanding consumer behavior as far as eating is concerned, by developing products that suit their lifestyles. The ready meal market has grown and one of the reasons for such growth is the search for convenience. Factors such as increased numbers of single people, search for convenience, increased participation of women in the labor market, demand for practicality, aging population, consumer prosperity, desire for new experiences, individuality, decrease in cooking skills, sharing of traditional meals, new technologies in conservation methods, packaging and food preparation and appearance of freezers and microwave ovens had a fundamental impact on the growth of the market for convenience foods.

As a limitation of this study, we point out the use of samples by convenience, which is not representative of the target population. The international marketing research represents a challenge to the researcher in that it deals with the same subject in different contexts; on the other 
hand, it is more complex than domestic research for various reasons, the most difficult of which is the access to the desired information, and the high cost of obtaining it (MALHOTRA, 2009). It is believed that the reported results should encourage further research relevant to both the development of new products and placement of products and brands active in these markets or even to identify new market segments or understand different generations of consumers.

\section{REFERENCES}

ASKEGAARD, S. An European regional analysis of selected food consumption statements. In: VAN RAAIJ, W. F.; BAMOSSY, G. (Eds.). European advances in consumer research. Provo, UT: Association for Consumer Research, 1993. v. 1, p. 410-415.

; MADSEN, T. K. The local and the global: exploring traits of homogeneity and heterogeneity in European food cultures. International Business Review, [S. 1.], v. 7, n. 6, p. 549-568, Nov. 1998.

BAE, H. J.; CHAE, M. J.; RYU, K. Consumer behaviors toward ready-to-eat foods based on food related lifestyles in Korea. Nutrition Research and Practice, Korea, v. 4, n. 4, p. 332-338, Aug. 2010.

BEATON, D. et al. Recommendations for the cross-cultural adaptation of health status measures. American Academy of Orthopedic Surgeons and Institute for Work \& Health. March, 2002.

BLACKWELL, R. D.; MINIARD, P. W.; ENGEL, J. F. Consumer behavior. Mason, Ohio: South Western, 2001.

BOURDIEU, P. Distinction: a social critique of the judgment of taste. London: Routledge, 1984.

BRUNSO, K.; SCHOLDERER, J.; GRUNERT, K. G. Testing relationships between values and food-related lifestyle: results from two European countries. Appetite, Amsterdam, v. 43, n. 2, p. 195-205, Oct. 2004.

BUCKLEY, M. et. al. The convenience consumer and food-related lifestyles in Great Britain. Journal of Food Products Marketing, Binghamton, v. 11, n. 3, p. 3-25, 2005.

CASOTTI, L. Comportamento do consumidor de alimentos: adoção de novos produtos e riscos associados. In: ENCONTRO NACIONAL DOS PROGRAMAS DE PÓS-GRADUAÇĀO EM ADMINISTRAÇÃO, 25., 2001, Campinas, Anais... Campinas: ANPAD, 2001.

COSTA, F. J. Mensuraçáo e desenvolvimento de escalas. Rio de Janeiro: Editora Ciência Moderna, 2011.

COSTA, A. I. A. et. al. To cook or not to cook: a means-end study of motives for choice of meal solutions. Food and Quality Preference, [S. 1.], v. 18, n. 1, p. 77-88, Jan. 2007.

DA MATTA, R. O que faz o Brasil, Brasil? Rio de Janeiro: Rocco, 2001.

FANG, C. H.; LEE, H. J. Food-related lifestyle segments in Taiwan: application of the foodrelated lifestyle instrument. American Journal of Applied Sciences, [Adelaide, SA], v. 6, n. 12, p. 2036-2042, Dec. 2009.

GEEROMS, N.; VERBEKE, W.; KENHOVE, P. V. Consumers' health-related motive orientations and ready meal consumption behavior. Appetite, Amsterdam, v. 51, n. 3, p. 704-712, Nov. 2008.

GRUNERT, K. G. et al. Food-related lifestyle: a segmentation approach to European food consumers. In: FREWER, L.; RISVIK, E.; SCHIFFERSTEIN, H. (Eds.). Food people and society: a European perspective of consumers' food choices. New York: Springer, 2001. p. 211-230.

GUERRERO, L. et al. Consumer-driven definition of TFP and innovation in traditional foods. A qualitative cross cultural study. Appetite, Amsterdam, v. 52, n. 2, p. 345-354, Apr. 2009. 
JAIN, S. International marketing management. Belmont, CA: Wadsworth Publishing Company, 1993.

JAMES, A. Cooking the books: global or local identities in contemporary British food cultures? In : HOWES, D. (Ed.). Cross-cultural consumption: global markets, local realities. London: Routledge, 1996. p. 77-92.

KESIC, T.; RAJH, S. P.; KESIC, H. Market segmentation in the Republic of Croatia according to food-related lifestyle. Ekonomiski Pregled, Zagreb, Croácia, v. 59, n. 9/10, p. 503-522, 2008.

LAMBIN, J. J. Marketing estratégico. Lisboa: McGraw-Hill, 2000.

MALHOTRA, N. K. Introduçáo à pesquisa de marketing. 4. ed. São Paulo: Pearson Prentice Hall, 2009.

MALUF, R. S. Consumo de alimentos no Brasil: traços gerais e açôes públicas locais de segurança alimentar. Pólis Papers, São Paulo, n. 6, 2000.

MOWEN, J. C.; MINOR, M. Consumer behavior. New Jersey: Upper Saddle River, 1998.

OLSEN, N. V. Predicting European consumer's intention to consume ready-to-eat meals. The role of moral attitude. Appetite, Amsterdam, v. 55, n. 3, p. 534-539, Dec. 2010.

PEDHAZUR, E. J.; SCHMELKIN, L. P. Measurement, design, and analysis: an integrated approach. New York: Psychology Press, 1991.

REID, M. et al. Food-related lifestyles in a cross-cultural context: comparing Australia with Singapore, Britain, France and Denmark. Journal of Food Products Marketing, Binghamton, v. 7, n. 4, p. 57-75, 2001.

ROKEACH, M. The nature of human values. New York: The Free Press, 1973.

RYAN, I. et al. Food-related lifestyle segments in Ireland with a convenience orientation. Journal of
International Food \& Agribusiness Marketing, Binghamton, v. 14, n. 4, p. 29-47, 2002.

et al. Segmenting Irish food consumers using the food-related lifestyle instrument. Journal of International Food \& Agribusiness Marketing, Binghamton, v. 16, n. 1, p. 89-114, 2004

SCHOLDERER, J.; GRUNERT, K. G. Consumers, food and convenience: the long way from resource constraints to actual consumption patterns. Journal of Economic Psychology, Amsterdam, v. 26, n. 1, p. 105-128, Feb. 2005.

SHETH, J. N.; MITTAL, B.; NEWMAN, B. I. Customer behavior: consumer behavior and beyond. Fort Worth, TX: The Dryden Press, 1999.

SHIMP, T. A.; SHARMA, S. Consumer ethnocentrism: construction and validation of the CETSCALE. Journal of Marketing Research, Chicago, v. 24, n. 3, p. 280-289, Aug. 1987.

SOLOMON, M. R. O comportamento do consumidor. 9. ed. Porto Alegre: Bookman, 2010 .

VANHONACKER, F. et al. Profiling European traditional food consumers. British Food Journal, Bradford, v. 112, n. 8, p. 871-886, 2010.

VERLEGH, P. W. J.; CANDEL, M. J. J. M. The consumption of convenience foods: reference groups and eating situations. Food Quality and Preference, Oxford, v. 10, n. 6, p. 457-464, Nov. 1999.

WANSINK, B.; PARK, S. Accounting for taste: prototypes that predict preference. Journal of Database Marketing, London, v. 7, n. 4, p. 308-320, 2000a.

Methods and measures that profile heavy users. Journal of Advertising Research, New York, v. 40, n. 4, p. 61-72, Aug./ Sept. 2000b. 
WELLS, W. D.; TIGERT, D. J. Activities, interests and opinions. Journal of Advertising Research, New York, v. 11, n. 4, p. 27-35, Aug. 1971.

WONG, N.; R I N D F L E I S C H , A .; BURROUGHS, J. E. Do reverse-worded items confound measures in cross-cultural consumer research? The case of the material values scale. Journal of Consumer Research, Chicago, v. 30, n. 1, p. 72-91, June, 2003.

WRIGHT, L. T.; NANCARROW, C.; KWOK, P. M. H. Food taste preferences and cultural influences on consumption. British Food Journal, Bradford, v. 103, n. 5, p. 348-357, 2001. 